\title{
СТИЛИСТИЧЕСКИЕ СРЕДСТВА ВЫРАЖЕНИЯ АНТИМОДЕРНИЗМА В ТВОРЧЕСТВЕ ПОЗДНЕГО ОЛЕСЯ БЕРДНИКА
}

\begin{abstract}
В статье рассматриваются стилистические средства выражения антимодернизма в позднем творчестве выдаюшегося украинского писателя Олеся Бердника, одного из ярчайших представителей отечественной научной фантастики. Материалом для исследования служат его романьл «Звёздный корсар», «Огнесмех» и некоторые произведения малой формыл. Выясняется, что поздний этап его творчества ознаменовался глубокой мировоззренческой трансформаџией, вследствие чего авторский нарратив со временем вступает в антагонизм с ключевыми принципами доктрины трансгуманизма, приобретая выраженные черты антипрогрессизма, антисциентизма, антитехницизма, антиинтеллектуализма и прочих форм традиционализма. Это проявляется, в частности, в активном использовании негативно окрашенньх эпитетов, гиперболических метафор, метонимических олицетворений и других выразительных средств, формирующих особые черты его идиостиля. Задействованный писателем арсенал тропов и стилистических фигур, как правило, содержит элемент оиенки, в данном случае преимущественно негативной. Бердником критикуется идея «сильного» искусственного интеллекта и индивидуального бессмертия, а рационально-позитивистская картина мира вытесняется космистскими и религиозно-мистическими теориями, руссоистским проектом возвращчения к природе, к традициям предков. Писатель разочаровывается в точных науках и научно-техническом пути развития, пересматривая их роль в эволюиионном прочессе человека и общества. Это оказывает влияние как на жанр создаваемых им работ, так и на их стилистический почерк, отличительной особенностью которого является повышенная эмфатичность: торжественно-приподнятый, нарочито высокопарный стиль, контрастность и яркость образов. Опираясь на классические дихотомии «естественный / искусственный», «сердиее / разум», он следует предупредительнылм трендам современной англоязычной фантастики.
\end{abstract}

Ключевые слова: биоконсерватизм, иммортализм, иррационализм, научная фантастика, неолуддизм, трансгуманизм, энвайроментализм.

Поль ДОНЕЦь, orcid.org/0000-0001-6759-0920 викладач кафедри перекладу та мовознавства Міжнародного гуманітарного університету (Одеса, Україна) dp85@ukr.net

\section{СТИЛІСТИЧНІ ЗАСОБИ ВИРАЖЕННЯ АНТИМОДЕРНІЗМУ В ТВОРЧОСТІ ПІЗНЬОГО ОЛЕСЯ БЕРДНИКА}

У статті розглядаються стилістичні засоби вираження антимодернізму в пізній творчості видатного українського письменника Олеся Бердника, одного з найяскравіших представників вітчизняної наукової фантастики. Матеріалом для дослідження служать його романи «Зоряний корсар», «Вогнесміх» та деякі твори малої форми. З'ясовується, щзо пізній етап його творчості ознаменувався глибокою світоглядною трансформацією, унаслідок чого авторський наратив згодом вступає в антагонізм із ключовими принципами доктрини трансгуманізму, набуваючи виражених рис антипрогресизму, антисиієнтизму, антитехніцизму, антиінтелектуалізму та інших форм традиціоналізму. Це виявляється, зокрема, в активному використанні негативно забарвлених епітетів, гіперболічних метафор, метонімічних уособлень та інших виразних засобів, щчо формують особливі риси його ідіостилю. Задіяний автором арсенал тропів і стилістичних фігур зазвичай містить елемент оцінки, у иььму випадку переважно негативної. Бердник критикує ідею «сильного» штучного інтелекту й індивідуального безсмертя, а раиіонально-позитивістська картина світу змінюється в його творах космістськими та релігійно-містичними теоріями, руссоїстським проєктом повернення до природи, до традицій предків. Письменник розчаровується в точних науках і науково-технічному шляху розвитку, переглядаючи їхню роль в еволючійному прочесі людини й суспільства. Це впливає як на жанр створюваних ним робіт, так $і$ на їхній стилістичний почерк, видатною особливістю якого є підвищена емфатичність: урочисто-підведений, пишномовний стиль, контрастність і яскравість образів. Спираючись на класичні дихотомії «природний / итучний», «серие / розум», він наслідує попереджувальні тренди сучасної англомовної фантастики.

Ключові слова: біоконсерватизм, енвайронменталізм, іморталізм, ірраціоналізм, наукова фантастика, неолудизм, трансгуманізм. 


\section{Аонец ІІ. Стилистические средства вырахения антимодернивма ...}

\section{Paul DONETS, \\ orcid.org/0000-0001-6759-0920 \\ Assistant Lecturer at the Department of Translation and Linguistics \\ International Humanitarian University \\ (Odesa,Ukraine)dp85@ukr.net}

\section{STYLISTIC MEANS OF EXPRESSING ANTIMODERNISM IN OLES BERDNYK'S LATE NOVELS}

The article examines stylistic devices in which distinguished Ukrainian writer Oles Berdnyk expresses antimodernist
deas. The author is famous for being one of the brightest representatives of native science fiction. His late novels
Zorianyi Korsar", "Vohnesmikh" and some short stories of the same period have been chosen as an object to be
studied. It is found out that his late works underwent drastic philosophical changes, resulting in a gradual departure from
his previous views. The message translated by the author in a given period of his creative activity reproduces primarily
the ideas of anti-progressivism, anti-scientism, anti-technicism, anti-intellectualism and other forms of traditionalism. In
is simplest form, this is manifested in the active use of negatively colored epithets, hyperbolized metaphors, metonymic
embodiments and other stylistic means which shape central features of the author's idiostyle. The tropes and figures
f speech used by the writer are in most cases emotionally expressive, that is, they contain elements of value (mostly
egative, in this case). Berdnyk criticizes the idea of "strong" artificial intelligence and individual immortality. The
ational positivist worldview in his works is being replaced by cosmist, religious and mystical theories, by the Rousseau's
roject of returning back to nature, to the traditions of ancestors. The writer becomes disillusioned with the hard science,
the scientific and technological path of development, revising their role in the evolutionary process of man and society.

Постановка проблемы. В ходе предыдущего исследования нами было установлено, что раннее творчество выдающегося украинского фантаста О. П. Бердника имеет немало точек пересечения с набирающей нынче популярность философией трансгуманизма. Весомым аргументом в пользу данного тезиса может служить задействованный писателем арсенал изобразительно-выразительных средств языка - тропов и стилистических фигур (Донец, 2019: 101).

Цель статьи. Исходя из этого, у читателей может сложиться ошибочное впечатление, что это распространяется на всю библиографию упомянутого автора. Однако, как покажет дальнейший анализ, его творчество далеко не так однозначно, как кажется на первый взгляд. По целому ряду пунктов оно не просто различается, но и вступает в прямое противоречие с идейным базисом и принципами доктрины трансгуманизма. А в более поздних произведениях мировоззрение писателя и вовсе претерпевает кардинальную трансформацию, приобретая выраженные черты антимодернизма, антипрогрессизма, антисциентизма, антитехницизма, антиинтеллектуализма и прочих форм традиционализма с приставкой «анти-». С учётом сказанного выше, спешить с выводами и записывать всю прозу Бердника в разряд трансгуманистической всё же не следует. Доказательству этого утверждения мы и посвятим статью.
Актуальность исследования обусловлена прежде всего самосбывающимся характером трансгуманистических прогнозов, с одной стороны, и связанным с этим ростом алармистских настроений в обществе - с другой. Кроме того, как уже не раз отмечалось исследователями, уникальный, не имеющий аналогов идиостиль Бердника до сих пор остаётся малоизученным явлением, требуя новых подходов в расшифровке всех его смысловых пластов (Смаглій, 2018: 61).

Материалы и методы. При написании работы был задействован метод контент-анализа, используемый в лингвистических исследованиях для вычленения в текстовом массиве тех или иных слов и понятий. Согласно определению А. Н. Баранова, суть данного подхода заключается в том, чтобы на уровне слов и словосочетаний «сделать выводы об особенностях мышления и сознания автора текста - его намерениях, установках, желаниях, ценностных ориентациях» (Баранов, 2001: 247). Материалом для исследования послужили работы Бердника, относящиеся к более позднему периоду его творчества, прежде всего его magnum opus «Звёздный корсар», роман «Огнесмех» и примыкающие к ним рассказы и повести.

Изложение основного материала. Даже в ранних произведениях бросается в глаза категорическое неприятие Бердником идеи «сильного» искусственного интеллекта, за создание которого 
обычно выступают трансгуманисты. Угроза возникновения «электронной диктатуры» - одна из центральных сюжетообразующих тем его творчества, вызывающая у автора особую озабоченность. Писатель убеждён, что если человечеству удастся когда-нибудь создать автономный ИИ, то он непременно установит жёсткую автократию, загонит население в концлагеря и, опираясь на армии боевых роботов, поставит всё живое во Вселенной под угрозу уничтожения. Любая мыслящая машина (если только она не стремится стать человеком) изображается как нечто деструктивное, антигуманное и чуждое, а учёные, конструирующие их, представлены в роли антагонистов (вчених-маніяків), смотрящих на жизнь сквозь призму холодной логики и бесчувственной рациональности.

В подобных эпизодах доминирует лексика подчёркнуто негативной модальности (німі механічні створіння; армії страшних бойових машин; холодної, жорстокої машини, що хоче підкорити весь світ; борються з огидним світом машин - результатом виродження інтелекту). Особое место в этом ряду принадлежит эпитету «железный» (залізній потворі, Залізний Диктатор, залізна, непохитна воля Диктатора), применяемому по отношению к принципиальному и вместе с тем жестокому правителю. Превалируют антитетические конструкции, усиленные каскадом эпитетов (на зміну слабким і нікчемним смертним істотам - дріб'язковим, непослідовним, сварливим $i$ брудним - прийдуть машини - безсмертні, з залізною логікою, з безпомилковою реакиією, прийдуть $i$ підкорять весь Космос), риторическими вопросами (людський розум деградує, і скоро машини піднімуться вище людей? Замінити чудесний людський інтелект холодним розумом машини?), реже - анафорой в сочетании с лексическим повтором: Автомати добували в підземеллях руду, перетоплювали iï, обробляли і виготовляли деталі; автомати конструювали нові зразки смертоносної зброї, призначеної для знищення жсивого світу; автомати керували гігантськими енергетичними станціями. Без кіния автомати, автомати, автомати!

Наибольшую угрозу писатель видит в освобождении людей от интеллектуального труда, передаче искусственному интеллекту функций научно-технического и творческого мышления. Известное воззвание Ф. Герберта «Не заменяй машиной человеческий разум» может служить лейтмотивом большинства произведений его украинского коллеги (Герберт, 1992: 11). Цивилизации, полагающиеся во всём на технику, прозябают у Бердника в стагнации, а в одном из случаев даже деградируют до уровня человекообразных обезьян, что акцентируется с помощью оксюморона (еволюиія в антиеволюиійному тупику, в деградуючій круговерті) и метонимии (повели планету по інволюційному шляху).

Нравоучительный пафос такой иллюстрации тесно соприкасается с идеей Ж. Бодрийяра, согласно которой технологии оказывают деперсонализирующий эффект на человека и общество, стало быть, «доверить свой интеллект машине значит освободиться от всякой претензии на знание» (Бодрийяр, 2000: 75). Можно также провести идейную параллель с мыслью Л. Мамфорда, предостерегавшего: «Вместо того чтобы активно функционировать в качестве самостоятельной личности, человек станет пассивным, бесполезным и машиноуправляемым животным» (Мамфорд, 2001: 9).

На рубеже 50-60-х гг. в мировоззрении Бердника наметился глубокий идейный «перелом», в полную силу выплеснувшийся в романе «Звёздный корсар» - книге, традиционно считающейся вершиной его творчества. По наблюдению канадского профессора-слависта В. Смирнива, писатель демонстрирует в ней свой скептицизм в отношении точных наук и научно-технического пути развития, пересматривая их роль в эволюционном процессе человека и общества (Smyrniw, 1981: 10). Взамен он предлагает развивать в себе духовно-психическую энергию, которая позволит людям достичь бессмертия и стать всемогущими.

Раскрывается иррационалистическая философия автора: провозглашается ущербность техногенной цивилизации и рационального познания (то механістичні уявлення середньовічних учених, які передали нам у спадщину примітивний логічний апарат мислення), появляются сомнения в физических законах Вселенной и уверенность в невозможности познания объективной реальности. Согласно М. Р. Павлишину, Бердником двигало желание «создать романтическую альтернативу материалистической утопии, порождённой технологией и достижением коммунизма», а потому по своему философскому содержанию и эстетическому методу его поздние работы близки не столько к научной фантастике, сколько к произведениям ранних европейских романтиков, таких как Ф. Шлегель и Новалис (Pavlyshyn, 1983: 90).

Несмотря на всё ещё декларируемую направленность в грядущее, автор постоянно оглядывается назад в историю, обращается к мифологизированным образам прошлого (Запорожской Сечи и Древней Греции), в которых находит свой идеал. Если раньше писатель противопоставлял науку мистике (Невже для того найкращі представники 
людства иіною свого щзастя і життя збирали по крихтах знання $і$ будували для нас величний храм сучасної Науки, шоб ми при першому великому випробуванні втікали в хащі містики?), то теперь он сам раскрывает себя как философ-мистик (вернутися в лоно магічної ијілісності... відродити магічну людину). Своё отражение это находит и на стилистическом уровне, как, например, в данном отрывке, где экспрессия асиндетона в перечислительном ряду усилена синтаксическим параллелизмом и морфемным анафорическим повтором: прагнення в світ трансиендентного, позачуттевого, єднання з невидимим, невідчутним, небувалим, подолання бар'єру особистості, обмеженості індивіда, замкнутості в лабетах інтелекту.

Начиная с середины 60-х гг., в творчестве Бердника прочно закрепляются эзотерические, историософские, псевдонаучные и сказочнофольклорные мотивы. Наряду с фейерверком идей о безграничном совершенствовании и могуществе человека соседствуют, например, звездолёты, летающие с помощью музыки, а способность к левитации и телепортации приобретается за счёт голодания. Обращаясь к идеям гилозоизма и панпсихизма (з повним правом можна називати будь-який стан матерії життям на певному piвні), автор приходит к убеждению, что Земля представляет собой живой организм, который периодически избавляется от низкоморальных и низкодуховных цивилизаций как от ненужного балласта. Даже космос, к которому по-прежнему устремлены чаяния писателя, отныне надлежит исследовать не физическим, а телепатическим путём (вже півжиття я воюю з техніцистамиученими, доводячи їм, що Безмежність не можна завоювати ракетами; політ ракет, гримотіння машин, ефемерна потужність всієї технічноі цивілізачії хай стане зрозумілою поряд з польотом думки - віния всього буття).

Симптоматично, что упомянутый выше нарративный сдвиг хронологически совпал со взлётом в западной фантастике движения «Новой волны» с её нью-эйдж философией и приматом «чувственного» над «рациональным», предлагавшей, так же как и Бердник, исследовать внутренний космос вместо внешнего (космічність майбутньої людини була не в загальній технізації, не в оточенні кожного максимальною кількістю машин і пристроїв, а, навпаки, в космічності мислення, в космічності етично-моральних поглядів).

Таким образом, взгляды Бердника всё больше тяготеют к мировоззрению хиппи с их протестом против бездушного техницизма (там, де можна обійтись без громіздкої техніки, треба відкинути ii), руссоистским проектом возвращения к природе (але ж Земля обрала шлях аналітично-інтегрального пізнання, культ його - кібернетика) и увлечением духовным наследием Востока-прежде всего, Индии и Тибета. Последнее привело к формированию своеобразной авторской религии синкретического характера, в которой, по утверждению И. М. Гриньоха, христианское вероучение тесно переплетается с элементами индуизма, буддизма и славянского неоязычества (Гриньох, 1980: 21).

Коренным образом меняется взгляды Бердника по отношению к эволюции. Если раньше, опираясь на арсенал ярких метафор, он наставлял своего читателя не цепляться за существующую человеческую форму (треба розірвати деспотію форми, нав'язану нам природою; треба зруйнувати тиранію форми), то теперь он, наоборот, призывает следовать этой форме, находя её совершенной. Наглядным примером тому служит корабельный робот УР, воспитавший и вырастивший двух осиротевших детей. Механический помощник решает обзавестись биологическим телом для того, чтобы мыслить не только рационально, но и эмоционально, а главное - постичь суть незнакомого ему чувства - любви.

С точки зрения трансгуманистов, обладание неизменной, «природной» телесностью в данном случае отнюдь не является обязательным условием, а потому указанный подход критикуется ими как биоконсервативный и антропоцентрический (Киселёва, 2012: 83). Эволюционная концепция Бердника, по замечанию одного из критиков, имеет не протехнологическую, а скорее почвенническую направленность: вместо постепенного слияния человека с машиной он предлагает путь природного развития (Шкуров, 2010: 436).

Заметим, что именно любовь, а не технические усовершенствования, выступают для позднего Бердника ключом к сверхвозможностям, что демонстрируется посредством параллельной антитетической композиции: Замість живого проникнення в безмірність - моделювання всесвіту, замість розширення своїх почуттів - створення аналогів почуття, механічних пристроїв-протезів. Как указывает Т. А. Метелёва, человек, по Берднику, богоподобен потому, что генерирует любовь (Метельова, 2014: 45). Именно такая вера в сверхприродную магическую силу, резюмирует И. П. Гречаник, наделяет его персонажей сверхъестественными способностями (Гречаник, 2013: 217).

По этой причине концепция киборга больше не вызывает у фантаста симпатии: Нині серйозно розглядається проект створення кіборга штучної біолюдини, яка має замінити сучасний 
тип розумної істоти. Такий «супермен» мислиться надзвичайно сильним, різнобічно розвинутим, наділеним новими розмаїтими почуттями, яких не має звичайна людина. Я визнаю, така істота можлива, іï, безумовно, створять. Але ж вона не зможе любити, хоч деякі кібернетики вважають, щуо любов можна запрограмувати. Приведённый отрывок демонстрирует чётко оформившуюся дихотомию «сердце - разум», где второе занимает в аксиологической иерархии автора низшее место, что маркируется с помощью метонимии (Серие згасало, над усім панував Розум).

Значительную эволюционную перемену претерпевает и отношение писателя к идее иммортализма. Исследователи сходятся на том, что мечтами о бессмертии охвачены герои почти всех его произведений, однако в поздних работах это бессмертие уже не материального характера, а, скоpeе, духовного (Чернова, 2007: 192). Если раньше смерть описывалась Бердником как проблема, которую можно и нужно решить научным путём (інститут вирішуе проблему безсмертя; в час, колирозв'язується проблема безсмертя), то теперь постулируется нечто диаметрально противоположное (проблема Хроноса лежить не в тій площині, якою рухається сучасна технізована наука).

Иммортологический концепт Homo Immortalis со временем вытесняется у Бердника диалектическим отрицанием смерти (Я не боюся смерті, бо ї̈ нема! С лише вічна заміна старого новим!) и постулированием непреходящести жизни как таковой (Неможливо вбити нікого й нічого! Все суще вічне й невразливе!). Истинная же вечность, пишет он, кроется в явлениях иного характера в творчестве, искусстве, памяти потомков: Так, особа вмирає. Але ми зовсім інакше дивимось на життя і смерть. Людина, особа виникає не на пустому місиі, а як результат минулих вдосконалень. <...> Все найкраще, щуо є в тобі, в мені, буде жити. В твоїх дітях, у дітях інших людей, y квітах, у музиці, в красі Безмежжя, яке несе в своєму лоні всіх пас-всі видимі і невидимі проявлення. Куди нам, синку, подітися від нашої Матері Безмежності? Ми справді безсмертні. Подобная интерпретация отвергается трансгуманистами как неприемлемая, поскольку лишает необходимости бороться за физическое бессмертие.

Со временем писатель и вовсе приходит к отрицанию научного иммортализма, усиливая категоричность своих суждений анафорическим параллелизмом: Не треба містичних вигадок. Не треба пошуків особистого безсмертя. Воно неможливе. Особисте безсмертя - страшна химера. Хіба може бути вічною конечна форма? Хіба можна затиснути безмежне в обмежене? Нi. Смерть же, напротив, воспринимается им как естественный порядок вещей, который нельзя нарушать. Стилистически это, как правило, выражается в виде парадоксов (Я не боюся смерті, я радію ӥй, бо це зміна форми... В иьому радість життя. Якби не було смерті - не було б розвитку) и олицетворения (Mu зупинили фізичну смерть людини, але природа помстилась нам. Не можна порушувати рівноваги).

Иммортологическая утопия, достигнутая жителями планеты Ара в «Звёздном корсаре» (наука Ари вже давно-давно розгадала таємниці старіння, подолала межу смерті і вивела мислячі істоти у світ нескінченного буття), на поверку оборачивается антиутопией - «золотой клеткой», в которой обречённые на застой и прозябание люди постепенно теряют всякое желание и мотивацию к жизни. Победа над старением и воцарившаяся экономика изобилия приводят к всеобщей апатии, морально-интеллектуальной деградации, росту преступности и самоубийств. Впрочем, даже суицид здесь лишён смысла: заботливые автоматы немедленно возвращают умершего к жизни. Тем самым Бердник критикует трансгуманистическую идею парадайзинжиниринга как потенциально опасную, что подаётся через антитетическую метафору: Людство, забезпечене всім необхідним, звиродніє $i$ скотиться в прірву інволюиії, що людині потрібен не добробут, а вічна небезпека і прірва, перед якою дух міг би виромувати крила для польоту! Недостойно для мислячої істоти замість залізних кайданів надівати діамантові!

Подводя итог вышесказанному, следует констатировать, что на протяжении творческой карьеры взгляды Бердника претерпели кардинальную трансформацию: от биомодернизма к биоконсерватизму, от научного иммортализма - к эзотерическому, от смертоборчества к смертничеству. Если ранние произведения ещё укладываются в рамки трансгуманистического дискурса, будучи по своему содержанию подчёркнуто техно-оптимистической и техно-утопической ретро-фантастикой, то его поздние работы соответствуют скорее трансцендентальному или психоделическому трансгуманизму.

Со стороны мейнстримовых трансгуманистов данное направление обычно критикуется за лженаучность и попытки привнести в и без того противоречивую доктрину элементы иррационализма и мистицизма. Согласно Р. Курцвейлу, оно толкает нас к витиеватому дуалистическому мировоззрению, которое учитывает трансцендентные уровни реальности (например, духовный уро- 
вень) (Kurzweil et al., 2002: 211). В. Эванс настаивает, что восточный эзотеризм несовместим с трансгуманизмом, и призывает не романтизировать теорию, разбавляя её компонентами религиозно-мистических учений (Evans, 2014: 96). Крупнейший бельгийский философ М. Бауэнс также считает спиритуальный и материалистический трансгуманизм идеологически оппонирующими друг другу платформами (Karaflogka, 2014: 101).

Вывод из вышесказанного напрашивается очевидный: творчество Бердника можно с уверенностью охарактеризовать как космистское, но к теме трансгуманизма оно имеет опосредованное отношение, распространяясь, как было доказано выше, лишь на небольшую часть его обширной библиографии. В пользу этого свидетельствует задействованный писателем арсенал изобразительно-выразительных средств языка (тропов и стилистических фигур), несущих в себе экспрессивно-эмоциональную окраску, то есть содержащих элемент оценки, которая постепенно меняется от преимущественно позитивной к столь же преобладающе негативной по отношению к науке и техническому прогрессу.

\section{СПИСОК ИСПОЛЬЗОВАННЫХ ИСТОЧНИКОВ}

1. Баранов А. Введение в прикладную лингвистику. М.: Эдиториал УРСС, 2001. 360 с.

2. Бодрийяр Ж. Прозрачность зла. М.: Добросвет, 2000. 258 с.

3. Герберт Ф. Дюна. Дюна. М.: Центрполиграф, 1992. С. 5-394.

4. Гречаник I. Багатосуб’єктність як конструкт хронотопної поліфонії у романах-феєріях Олеся Бердника. Житомирські літературознавчі студії. Житомир: ЖДУ, 2013. № 7. С. 215-221.

5. Гриньох І. Олесь Бердник. Утопіст чи харизматик на обрії другого тисячоліття християнства в Україні. Рим : Богословія, 1980. Т. $54.47 \mathrm{c}$.

6. Донец П. Стилистические средства выражения трансгуманизма в творчестве раннего Олеся Бердника. Науковий вісник ПНПУ ім. К. Д. Ушиисського: Лінгвістичні науки. Одеса : Астропринт, 2019. № 29. С. 92-103.

7. Киселёва Ю. Жизнь или пост-жизнь: полемика биоконсерватизма и биомодернизма как мировоззренческая оппозиция начала XXI века. Роль науки, релігї̈ та суспільства у формуванні моральної особистості. Донецьк: Наука і освіта, 2012. С. $83-85$.

8. Мамфорд Л. Миф машины. Техника и развитие человечества. М.: Логос, 2001. 408 с.

9. Метельова Т. Філософська антропологія Олеся Бердника: екзистенційні та постмодерністські інтенції. Українознавчий альманах. Мелітополь : МДПУ ім. Б. Хмельницького, 2014. № 16. С. $42-47$.

10. Смаглій І. Аксіологічна ієрархія земного і космічного у творах Олеся Бердника. Наукові записки БДПУ. Філологічні науки. Бердянськ : БДПУ, 2018. № 16. С. 60-69.

11. Чернова I. Фантастична умовність у прозі О. Бердника. Сучасні проблеми мовознавства та літературознавства. Ужгород : Говерла, 2007. № 11. С. 188-193.

12. Шкуров Є. Основні стратегії осмислення Homo futurus у фантастичній літературі (Бердник О. «Вогнесміх» та Нікітін Ю. «Транслюдина»). Літературознавчі студіï. Київ : Вид. дім Дмитра Бураго, 2010. № 29. С. 436-443.

13. Evans W. If You See a Cyborg in the Road, Kill the Buddha: Against Transcendental Transhumanism. Journal of Evolution and Technology. Willington : Institute for Ethics and Emerging Technologies, 2014. Vol. 24 (2). P. 92-97.

14. Karaflogka A. E-Religion: A Critical Appraisal of Religious Discourse on the World Wide Web. London : Routledge, 2014. $224 \mathrm{p}$

15. Kurzweil R. Richards J. W. Gilder G. F. Are We Spiritual Machines? Ray Kurzweil vs. the Critics of Strong A.I. Seattle : Discovery Institute Press, 2002. 222 p.

16. Pavlyshyn M. Oles Berdnyk's Okotsvit and Zorianyi Korsar: Romantic Utopia and Science Fiction. Journal of Ukrainian Studies. Toronto : University of Toronto Press, 1983. Vol. 8 (2). P. 89-101.

17. Smyrniw W. The Theme of Man-godhood in Oles Berdnyk's Science Fiction. Journal of Ukrainian Studies. Edmonton : CIUS Press, 1981. Vol. 6 (1). P. 3-19.

\section{REFERENCES}

1. Baranov A. Vvedenie v prikladnuiu lingvistiku [Introduction to Applied Linguistics]. M.: Editorial URSS, 2001. 360 p. [in Russian].

2. Baudrillard J. Prozrachnost zla [The Transparency of Evil]. M.: Dobrosvet, 2000. 258 p. [in Russian].

3. Herbert F. Duna [Dune]. M.: Tsentrpolyhraf, 1992. P. 5-394. [in Russian].

4. Hrechanyk I. Bahatosubiektnist yak konstrukt khronotopnoi polifonii u romanakh-feieriiakh Olesia Berdnyka [Poly-Subjectivity as a Construct of Chronotopic Polyphony in the Fairy-Novels by Oles Berdnyk]. Zhytomyr Literature Studies. Zhytomyr : ZSU, 2013. Vol. 7. P. 215-221. [in Ukrainian].

5. Hrynokh I. Oles Berdnyk. Utopist chy kharyzmatyk na obrii druhoho tysiacholittia khrystyianstva v Ukraini [Oles Berdnyk. Utopian or Charismatic Leader on the Horizon of the Second Millennium of Christianity in Ukraine]. Rome : Bohosloviye, 1980. Vol. 54. 47 p. [in Ukrainian].

6. Donets P. Stilisticheskie sredstva vyirazheniya transgumanizma v tvorchestve rannego Olesya Berdnika [Stylistic Means of Expressing Transhumanism in Oles Berdnyk's Early Novels]. Scientific Journal of SUNPU named after K. D. Ushynsky: Linguistic Studies. Odesa : Astroprynt, 2019. Vol. 29. P. 92-103. [in Russian]. 
7. Kiselyova Y. Zhizn ili post-zhizn: polemika biokonservatizma i biomodernizma kak mirovozzrencheskaya oppozitsiya nachala XXI veka [Life or Post-life: the Controversy between Bioconservatism and Biomodernism as a Worldview Opposition at the Beginning of the $21^{\text {st }}$ Century]. The Role of Science, Religion and Society in the Formation of Moral Personality. Donetsk : Science and Education, 2012. P. 83-85. [in Russian].

8. Mumford L. Mif mashinyi. Tehnika i razvitie chelovechestva [The Myth of the Machine. Technics and Human Development]. M.: Logos, 2001. 408 p. [in Russian].

9. Metelova T. Filosofska antropolohiia Olesia Berdnyka: ekzystentsiini ta postmodernistski intentsii [Oles Berdnyk's Philosophical Anthropology: Existential and Postmodern Intentions]. Ukrainian Studies Almanac. Melitopol : MSPU named after Bogdan Khmelnytsky, 2014. Vol. 16. P. 42-47. [in Ukrainian].

10. Smahlii I. Aksiolohichna iierarkhiia zemnoho i kosmichnoho u tvorakh Olesia Berdnyka [Axiological Hierarchy of Terrestrial and Cosmic in Oles Berdnyk's Works]. Scientific Notes of BDPU. Philological Sciences. Berdiansk : BDPU, 2018. Vol. 16. P. 60-69. [in Ukrainian].

11. Chernova I. Fantastychna umovnist u prozi O. Berdnyka [Fantastic Conventionality in O. Berdnyk's Prose]. Modern Problems of Linguistics and Literary Criticism. Uzhhorod : Hoverla, 2007. Vol. 11. P. 188-193. [in Ukrainian].

12. Shkurov Y. Osnovni stratehii osmyslennia Homo futurus u fantastychnii literaturi (Berdnyk O. "Vohnesmikh" ta Nikitin Y. "Transliudyna") [Basic Strategies of Homo Futurus Comprehension in Fiction (Berdnyk O. "Vohnesmikh" and Nikitin Y. "Transhuman”)]. Literature Studies. Kyiv : Publishing House of Dmitry Burago, 2010. Vol. 29. P. $436-443$.

13. Evans W. If You See a Cyborg in the Road, Kill the Buddha: Against Transcendental Transhumanism. Journal of Evolution and Technology. Willington : Institute for Ethics and Emerging Technologies. 2014. Vol. 24 (2). P. $92-97$.

14. Karaflogka A. E-Religion: A Critical Appraisal of Religious Discourse on the World Wide Web. London : Routledge, 2014. $224 \mathrm{p}$.

15. Kurzweil R., Richards J. W., Gilder G. F. Are We Spiritual Machines? Ray Kurzweil vs. the Critics of Strong A.I. Seattle : Discovery Institute Press, 2002. 222 p.

16. Pavlyshyn M. Oles Berdnyk's Okotsvit and Zorianyi Korsar: Romantic Utopia and Science Fiction. Journal of Ukrainian Studies. Toronto : University of Toronto Press, 1983. Vol. 8 (2). P. 89-101.

17. Smyrniw W. The Theme of Man-godhood in Oles Berdnyk's Science Fiction. Journal of Ukrainian Studies. Edmonton : CIUS Press, 1981. Vol. 6 (1). P. 3-19. 